\title{
GEOTHERMAL RESOURCES: NEW INSIGHTS FOR SPA TOURISM IN NORTH MACEDONIA
}

DOI: https://doi.org/10.18509/GBP210127ch

UDC: 338.483.11:553.7(497.7)

\author{
Vlatko Chingoski ${ }^{1}$ \\ Biljana Petrevska ${ }^{2}$ \\ ${ }^{1}$ Faculty of Electrical Engineering, Goce Delčev University, Štip, North Macedonia \\ ${ }^{2}$ Faculty of Tourism and Business Logistics, Goce Delčev University, Štip, North Macedonia
}

\begin{abstract}
Geothermal energy resources have been used several thousand years ago for many purposes, but mainly for health and wellness treatments. Many hot springs have come and gone over time, yet many are still unrevealed and unused. The aim of the paper is to put some insights into new and less-known geothermal locations dispersed over the territory of North Macedonia, along with their potential for developing new spa tourism resorts. Based on a content analysis of various documents related to geothermal energy, the research applied the expert's judgment and proposed a map presenting new geothermal resources. As such, new potential for more extended spa tourism occurs, which may be successfully implemented for developing modern and attractive tourist locations. Finally, the paper suggests many recommendations for better understanding the complexity of the power that geothermal energy has, but only if been adequately implemented in planning the spa tourism development.
\end{abstract}

Keywords: Geothermal energy, Tourism development, Spa, Balneotherapy.

\section{INTRODUCTION}

Water and Energy are the two main subjects that define the existence, survival, and development of humanity. Wherever is water, there is life, and wherever is water and energy, life expands. Thus, water and energy are always considered key preconditions for life.

Thermal and mineral waters are a special category of groundwater being used several thousand years ago for drinking, bathing, healing, therapy, or religious purposes. Even from the pre-history, people have believed in the curative powers of the water springs in the places in which they naturally occur [11]. Today, both, thermal and mineral waters are used mostly for balneology, water bottling industry, and for geothermal energy, contributing significantly to economic development. Due to fact that this kind of water is heated from the embedded heat within the Earth, they are treated as sources of geothermal energy. It is a fact that many hot springs have come and gone over time, yet many are still unrevealed and unused. As such, they may become new sources for supporting economic development.

Archaeological findings show that mineral and thermal waters have been used for bathing since the Bronze Age (about 12,000-3,000 years BC) [11]. The location of human settlements in the vicinity of hot springs took place in many areas in the world and many periods of human history, mostly because humanity has associated certain mineral and thermal water springs with divine powers of healing. Ancient Greeks developed the school of physiotherapy and balneology based upon geothermal waters and herbs. They 
are also the authors of the popular maxim "health from water." Romans took over this motto, which is currently known as "SPA" - Salud per aquam in Latin comes from the abbreviation for $\mathrm{S}=$ Salud, $\mathrm{P}=$ per, $\mathrm{A}=$ aqua, or "Health through Water." In Germany, they refer to the "Kur", which does not mean just a cure, but instead is a series of treatments over time including baths, taking (drinking) water, massage, exercise, mud baths, etc. [7].

Geothermal energy as the primary energy source can be utilized in various ways such as district heating, food production in green-houses, drying agricultural products, etc. This research focuses on using geothermal energy as a resource for thermal and mineral waters for recreational and therapeutic purposes. More precisely, the paper adds to the current state of the art on the positive effects of geothermal energy resources for tourism development, especially spa tourism development. In this line, the study highlights some new and less-known geothermal locations in North Macedonia with excellent potential for developing new balneotherapy and wellness facilities as tourism resorts [4].

The introduction is followed by a background material on geothermal energy and geothermal waters in general, along with some stylized facts for geothermal waters in North Macedonia as a study area. The next section presents the applied methodology, followed by a discussion and conclusion. The study contributes to the current literature on spa tourism and geothermal resources in North Macedonia as already previously discussed $[1 ; 5]$

\section{BACKGROUND MATERIAL}

\section{Geothermal energy and geothermal waters}

Water is a transparent fluid which forms all water-based objects on the Earth such as oceans, rivers, lakes, ice caps, streams, and rains that are essential for life on our planet. About $71 \%$ of the Earth's surface is covered with water, of which about $97 \%$ is stored as salt water in oceans, leaving only $2,5 \%$ as freshwater stored in glaciers and ice caps, groundwater, and soil moisture. It is almost unbelievable that of such a huge amount of water present on Earth, only a very small percentage $(\sim 1 \%)$ is available for humans as freshwater for drinking and other purposes like heating, cooling, industry, tourism, and recreation [11] (Figure 1).

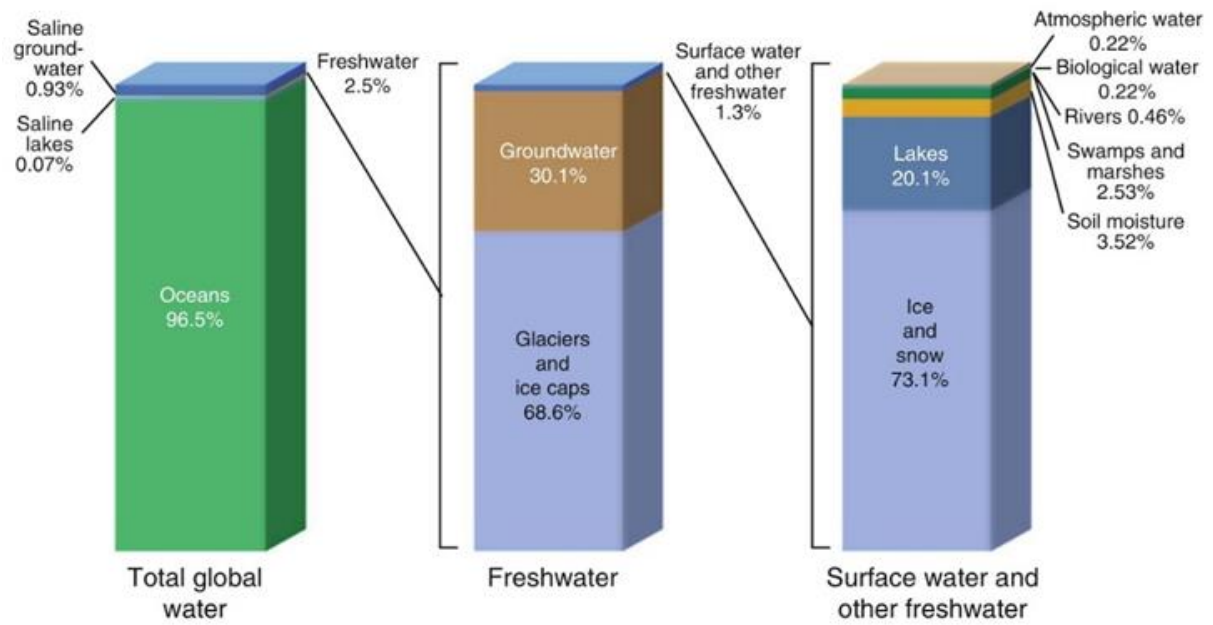

Figure 1: Distribution of Earth's water Source: [11]. 
Speaking of energy, the Sun is the main energy source on Earth, either in its primary form as solar energy, or in its secondary forms as stored energy in the forms of nuclear, chemical, or fossil fuels. Recently, the so-called renewable energy resources such as solar, wind, ocean, biothermal, or geothermal energy gradually replaced the conventional energy resources of fossil type such as coal, naphtha, or natural gas.

Geothermal energy comes deeply hidden from the Earth, and its presence on the surface is quite scattered and uneven. It is sometimes in a form of warm or even hot water streams, steam sources, and sometimes a mixture of steam and water in a form of geysers. Going deeper into the Earth's crust, the temperature of the soil rises resulting in hotter geothermal water reservoirs that could be technically brought up to the earth's surface and further utilized as energy sources (Figure 2).

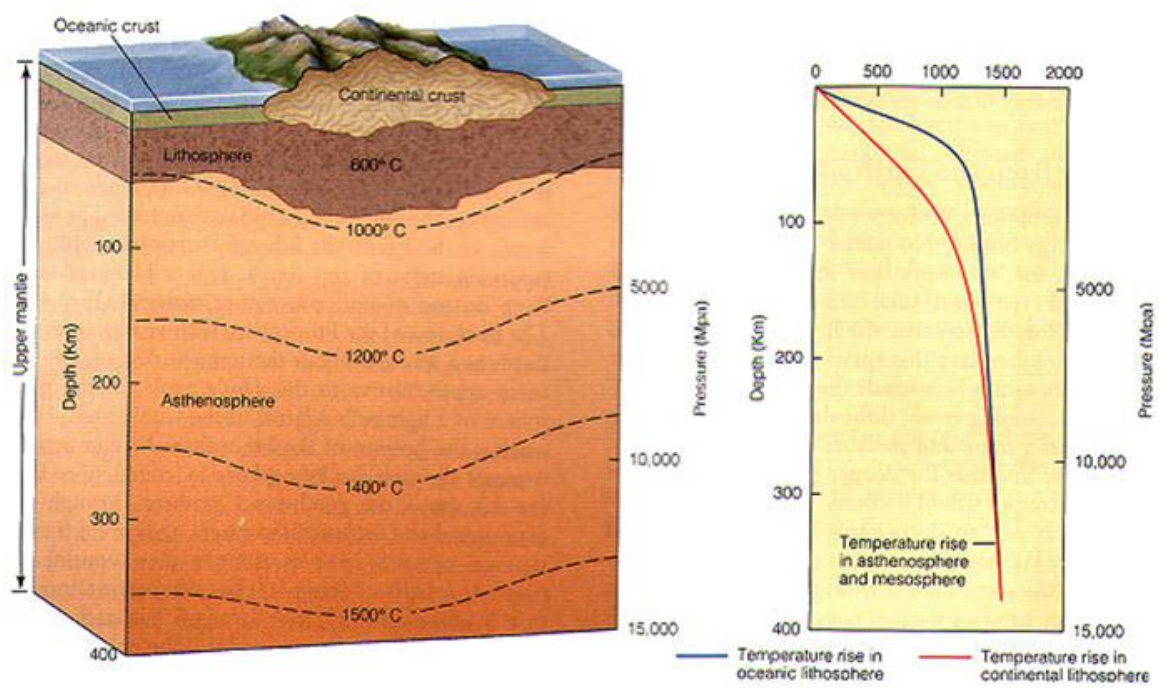

Figure 2: Geothermal temperature gradient Source: [6].

Initially, only two basic ways of formation and heating of thermal waters are possible: the juvenile (primal or volcanic) and vascular (constantly renewed meteoric or rainwater) [13]. Yet today the origin of thermal and thermo-mineral waters expands and based on the origin, five types of thermal waters are distinguished [16]: juvenile (volcanic), conical (fossil), quarters (young), vascular (wade of water), and mixed waters. Accordingly, their main characteristics, in general, depending on the depth from which they originate, the temperature, the content of minerals, gases, and micro components, related to the physiotherapeutic effect on the body, and the content of physiological groups of bacteria (indigenous microflora).

\section{Study area: North Macedonia}

The utilization of (geo)thermal waters in the territory of North Macedonia traces its origin from Roman times. Several locations with thermal waters, mostly in the eastern and northeastern parts of North Macedonia (Figure 3) were well-known and utilized in that period for health treatment of roman soldiers, recreation, and fun for the upper-class Roman citizens. Some locations were continually used as thermal and mineral water facilities for centuries, being famous when North Macedonia was part of the former Yugoslavia (end of 19th and whole 20th century) [9]. 


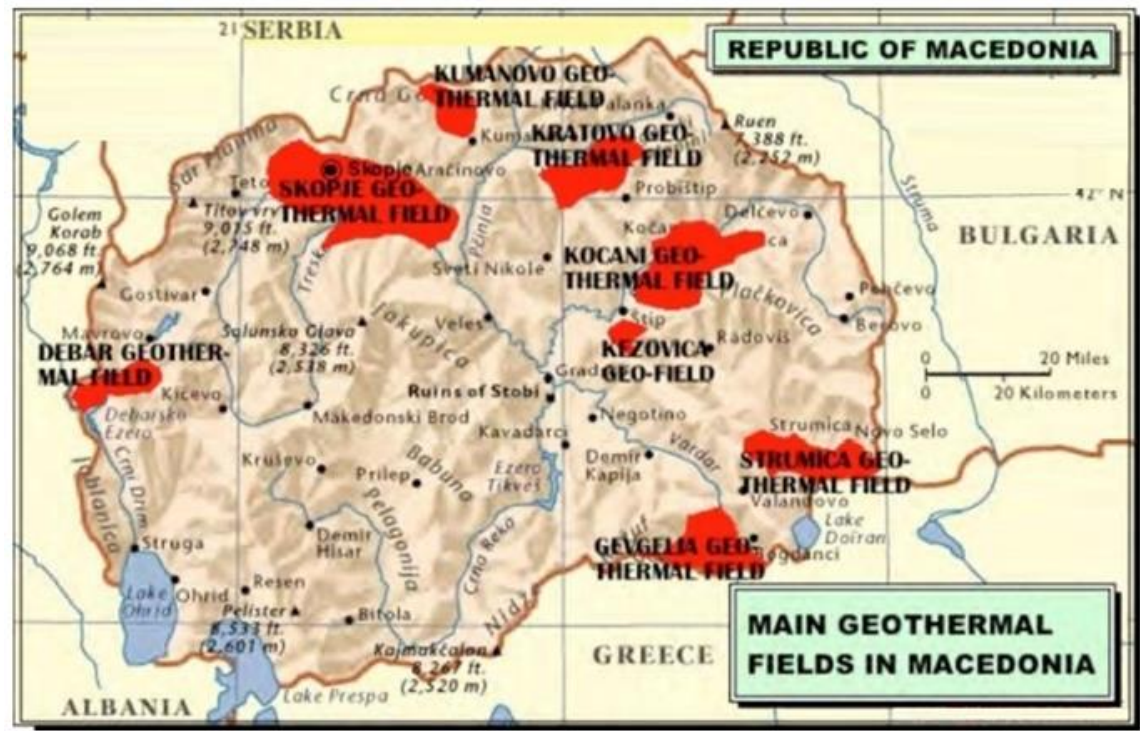

Figure 3: Spatial distribution of major geothermal fields in North Macedonia Source: [14].

The territory of North Macedonia belongs to the Alpine-Himalayan zone, with subzones without any modern volcanic activity. So far, seven geothermal fields are active with eight spa centers (Table 1). Their spring capacity spreads between 4-100 1/sec with a temperature range between $31-75^{\circ} \mathrm{C}$. The geothermal waters of these fields have a hydrocarbon nature, given their dominant anionic and mixed chemical structure with the equal presence of sodium, calcium, and magnesium. Due to the low temperature of the geothermal waters, their geothermal energy is barely used as a renewable source of energy in the country. For five years from 2001 till 2006, the use of geothermal energy declined from 21 ktoe per year to only 9 ktoe in 2006. According to the Energy Balance for 20152019 , geothermal energy participated with $2.36 \%$ in the national energy balance of renewable energy sources [12]. Thus, of all eight geothermal fields presented in Fig. 3, only the Kočani and partially Gevgelija geothermal fields are currently used as a heat source for the local green-house facilities, apart from modest spa and balneotherapy tourism.

Table 1. Active geothermal locations in North Macedonia

\begin{tabular}{|c|c|c|c|c|c|c|c|c|c|c|}
\hline \multirow[t]{2}{*}{ No. } & \multirow[t]{2}{*}{ Spa/Geothermal field } & \multirow{2}{*}{ 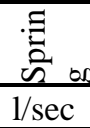 } & \multirow{2}{*}{$\frac{\Xi}{\stackrel{E}{\theta}}$} & \multicolumn{7}{|c|}{$\begin{array}{l}\text { Heat Capacity }(\mathrm{MWt}) \\
\text { (for a different temperature of the thermal water) }\end{array}$} \\
\hline & & & & $15^{\circ} \mathrm{C}$ & $20^{\circ} \mathrm{C}$ & $25^{\circ} \mathrm{C}$ & $30^{\circ} \mathrm{C}$ & $35^{\circ} \mathrm{C}$ & $40^{\circ} \mathrm{C}$ & $45^{\circ} \mathrm{C}$ \\
\hline 1 & Bansko/Strumica & 50 & 70 & 11.5 & 10.5 & 9.4 & 8.4 & 7.3 & 6.3 & 5.2 \\
\hline 2 & Debar Spa/Debar & 100 & 40 & 10.5 & 8.4 & 6.3 & 4.2 & 2.1 & - & - \\
\hline 3 & Katlanovo/Skopje & 13 & 50 & 1.9 & 1.6 & 1.4 & 1.1 & 0.8 & 0.5 & 0.2 \\
\hline 4 & Kežovica/Štip & 20 & 60 & 3.8 & 3.4 & 2.9 & 2.5 & 2.1 & 1.4 & 1.3 \\
\hline 5 & Kočani Spa/Kočani & 300 & 75 & 75.4 & 69.1 & 62.8 & 56.5 & 50.2 & 44.0 & 37.7 \\
\hline 6 & Kosovrasti/Debar & 60 & 48 & 8.3 & 7.0 & 5.8 & 4.5 & 3.3 & 2.0 & 0.7 \\
\hline 7 & Kumanovo Spa/Kumanovo & 4 & 31 & 0.3 & 0.2 & 0.1 & - & - & - & - \\
\hline 8 & Negoska Spa/Gevgelija & 80 & 50 & 11.7 & 10.1 & 5.4 & 6.7 & 5.0 & 3.4 & 1.7 \\
\hline
\end{tabular}

Source: Modified upon [3, 4] and authors' content analysis

As one can see from Table 1, this low percentage of utilization of geothermal source for electrical energy generation mostly depends on two factors, the lower temperature of the geothermal water which results in poor economic justification, and the needs for 
significant investments for deep drilling to achieve geothermal resources with sufficiently high temperature applicable for electricity generation (Table 2). Drilling to such depths needs advanced technology and large investments, resulting in a high price for the generated electricity which could be economically not acceptable for the customers. Considering these relatively low temperatures of geothermal and thermo-mineral waters, they should predominantly be used for balneological purposes by combining the naturalmineral and thermal spring water for treatment and cure of disease.

Table 2. Geothermal energy potential along river Vardar according to the drilling depths

\begin{tabular}{|l|l|l|l|}
\hline No. & Drilling Depth $(\mathrm{km})$ & Expected temperature $\left({ }^{\circ} \mathrm{C}\right)$ & $\begin{array}{l}\text { River Vardar Zone } \\
\text { Area }=8680 \mathrm{~km}^{2} \\
10^{21}[\mathrm{~J}]\end{array}$ \\
\hline 1 & $0-3$ & 176 & 10.4 \\
\hline 2 & $3-5$ & 290 & 12.0 \\
\hline 3 & $5-7$ & 406 & 17.0 \\
\hline 4 & $7-10 \quad 580$ & 36.9 \\
\hline \multicolumn{3}{|r|}{ TOTAL: } & 76.3 \\
\hline
\end{tabular}

Source: [2].

The principal minerals found in most mineral waters in the Macedonian geothermal fields are sodium, magnesium, calcium, and iron, in combination with the acids to form chlorides, sulfates, sulfides, and carbonates. Other substances occasionally present in sufficient quantity to exert a therapeutic influence are arsenic, lithium, potassium, manganese, bromine, iodine, and some radioactive materials, mostly radium, radon, and uranium [16]. Their different combinations determine possibilities for healing specific diseases or a combination of diseases by using different therapies.

Historically speaking, spa and balneotherapy tourism were relatively well developed in North Macedonia as a part of the former Yugoslavia. In the late 1980s, spa tourism in the country was at the same level as that of the other spa tourism resorts in the former Yugoslavia, such as Prolom, Soko, and Vrnjacka Banja in Serbia, Istrian and Tuhelj Toplice in Croatia or Chatež and Roman Toplice in Slovenia. However, after the dissolution of the former Yugoslavia, North Macedonia as the least developed, had no chance to keep the quality of its spa resorts, so they were left behind with investments and guests. The problem was further enhanced with the wars in the former Yugoslavia during the entire 1990s, thus leaving Macedonian spas without foreign guests and tourists. In that period, Macedonian spa resorts were used only as medical therapeutic facilities for domestic patients. As a result, from that period until today, only a few of them managed to work as spa tourism resorts in a more-or-less acceptable condition. So, Debar Spa, Katlanovska Spa, Kežovica Spa, Bansko Spa, and Negorska Spa are used mostly for medical therapeutic purposes and domestic patients. Most of them have undertaken just minor reconstructions and construction improvements in the furniture design and lodging. Yet, no modern spa and recreation units, indoor and outdoor pools, gym or fitness facilities, massage centers, and additional supplement units are added.

In general, in the last three decades, North Macedonia experienced a period of stagnation of geothermal development and utilization of geothermal energy. This was mostly due to a lack of investments and disputable ownership rights of the geothermal resources. As a result, during that period the use of geothermal energy declined significantly. In the same period, the spa resorts in other Yugoslavian republics, especially Croatia and Slovenia, and in the neighboring countries such as Bulgaria (Bansko, Velingrad, Pavlov Spa, etc.) experienced huge development and gradually became famous and well-established 
recreation centers attracting guests from the entire Balkan and wider. According to [8], the hotels with extensive spa facilities on average bring between $23-27 \%$ increase in the income per occupied room than the hotels with no spa facility. These figures show that resort spas are not only revenue generators, but also solid contributors to resorts' bottom line, besides other intangible benefits such as creating repeat business, increasing guest satisfaction, and influencing guests' future recreational preferences. Resort/hotel spas possess competitive and operational advantages over stand-alone spas both from a revenue and expense perspective. Hence, available geothermal source should not be treated only as medical therapeutical location, but as viable and profitable tourism and revenue bringing resource.

However, to achieve this and to come to the point that North Macedonian spa resorts could be revenue bringing resources, new potential geothermal sources are investigated along with the fact that the current ones need a large scale of renovation and reconstruction. Having in mind that in $2019,90 \%$ of registered tourists that visit current spas were domestic with an average duration of stay of 8.7 days [12], some substantial increase of revenues can neither be expected nor achieved. This confirms the fact that presently spas in North Macedonia are used only for medical treatments, thus missing the opportunity to develop as complex wellness centers.

\section{METHODOLOGY, DATA AND RESULTS}

The study is based on qualitative data obtained by secondary sources. An in-depth review is made of relevant literature addressing the issue of geothermal resources and their usage in tourism development. During the desk research analysis, the focus was on the following research questions (RQ):

RQ1: Which are the new geothermal resources?

RQ2: What is the geothermal energy potential of the less-known geothermal locations dispersed over the territory of North Macedonia?

RQ3: Which measures to recommend for developing new spa tourism resorts in North Macedonia?

Based on the content analysis of various documents with a study area of North Macedonia, the study proposes less-known geothermal fields and geothermal locations (Table 3), which are visually presented in Figure 4

\section{DISCUSSION AND CONCLUSION}

Regarding the tourism industry, the biochemical and physical properties of the geothermal and mineral waters are very important. Thus, the minerology of the (geo)thermal waters has crucial value, besides the water temperature, to define their quality and suitability for medical and balneological use. High-quality mineral waters, when analyzed, should contain many chemical substances, although, some of them occur only in very minor quantities.

The most common utilization of thermal and mineral waters is in the specially designed and programed bathtubs under adequate medical control or the open or closed water pools, for swimming or simply relaxation and medical treatments. They are oriented toward the thermal treatment of the whole human body by absorption of the minerals through the body skin, on one side, or for rehabilitation treatments and re-mobilization of moving parts of the human body and skeleton. 
The second way to use the thermal and mineral waters is by drinking. Therapeutically, drinking mineral water provides a washing out of the human intestines, which on one side temporary increase in certain body fluids excretions, augmented diuresis, and sweat, and on the other side, warm water is better absorbed by the stomach resulting in higher therapeutic action to the human body than cold water.

The research revealed that spa tourism in North Macedonia may be extended with the new potential that less-known geothermal locations offer. Figure 4 presents a map with visual presentation of 13 newly selected geothermal locations in North Macedonia, based on the experts' judgment of the authors.

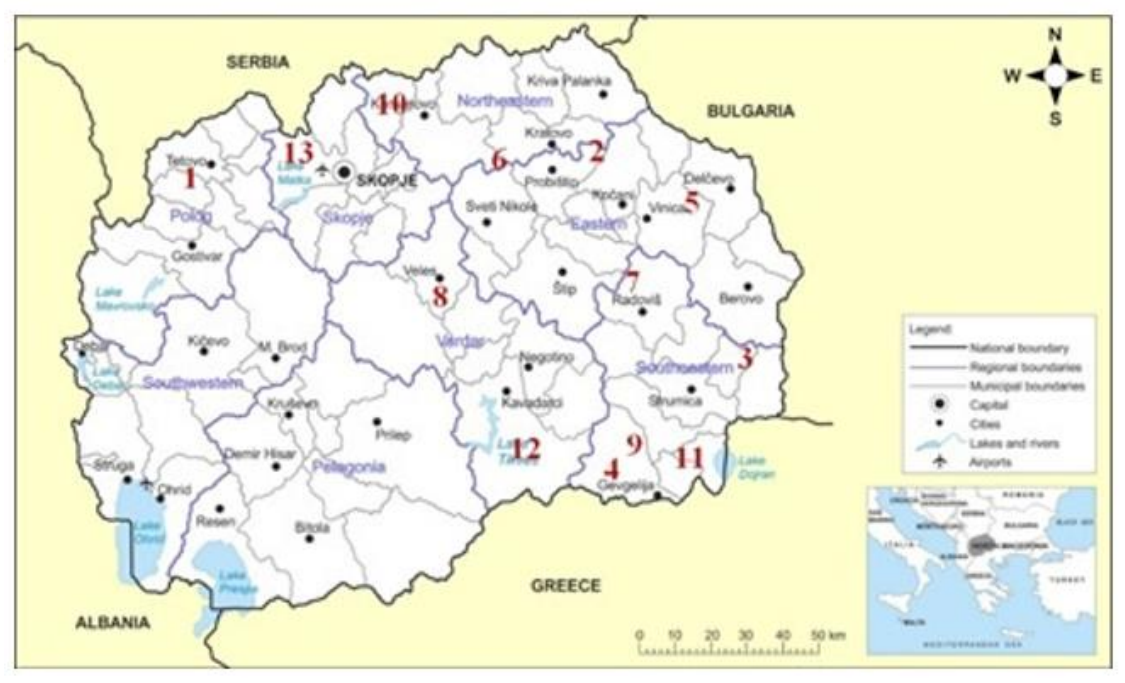

Figure 4: Less-known geothermal locations in North Macedonia Source: Modified upon [15: p. 6]
Legend:

1-Baniče/Tetovo

2-Dobrevo/Zletovo

3- Drvoš-

Baldovci/Strumica 4-Gorničet/Gevgelija

5-Istibanja/Vinica

6-Zdravevci/Kratovo

7- Rakliš/Radoviš

8-Sabota Voda/Veles

9- Smokvica/Gevgelija

10-Strnovec/Staro

Nagoričane

11-Toplec-Dojran

12-Topli dol \&

Mrežičko- R'žanovo/

Kavadarci

13- Volkovo/Skopje

Based on Figure 4, it is visible that the newly identified geothermal locations are dispersed only on one half of territory of North Macedonia, mainly covering the Skopje region, eastern, central and south part. One geothermal field is very near Skopje (Volkovo No. 13 in Fig. 4), one is near Tetovo (Baniče No. 1 in Fig. 4), one is $40 \mathrm{~km}$ from Skopje in Staro Nagoričane (Strnovec No. 10 in Fig. 4), one is in the central part of the country in Veles (Sabota Voda No. 8 in Fig. 4), four are in the eastern part (Dobrevo in Zletovo No. 2, Istibanja in Vinica No. 5, Zdravevci in Kratovo No. 6, and Rakliš in Radoviš, No. 7 in Fig. 4), and the rest of five geothermal locations are dispersed mainly in the south part (Drvoš-Baldovci in Strumica No. 3, Gorničet in Gevgelija, No. 4, Smokvica in Gevgelija No. 9, Toplec in Dojran No. 11, and Topli dol \& Mrežičko-R'žanovo near Kavadarci No. 12 in Fig. 4).

Table 3 presents the energy potential of 13 newly identified less-known geothermal locations/fields in North Macedonia. They are of quarters (young) meteoric origin with a spring capacity spreading between $2-120 \mathrm{l} / \mathrm{sec}$ and temperature between $24-120^{\circ} \mathrm{C}$. Although the temperatures of the geothermal waters are too low to be considered for electricity generation, the existing geothermal resources have huge potential as thermal heating resources in the agriculture industry for greenhouse heating and agriculture products drying, and in the tourism industry as balneological treatment facilities, and spa and wellness resorts. 
Table 3: Energy potential of less-known geothermal locations/fields in North Macedonia

\begin{tabular}{|c|c|c|c|c|c|c|c|c|c|c|}
\hline$\stackrel{\Xi}{\Xi}$ & $\begin{array}{l}\text { Geothermal } \\
\text { location/field }\end{array}$ & है & 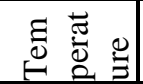 & $\begin{array}{l}\text { Heat } \\
\text { (for a }\end{array}$ & $\begin{array}{l}\text { apacity } \\
\text { lifferen }\end{array}$ & $\begin{array}{l}\text { (MWt) } \\
\text { temper }\end{array}$ & ature of & the the & mal wa & \\
\hline & & $1 / \mathrm{sec}$ & ${ }^{\circ} \mathrm{C}$ & $15^{\circ} \mathrm{C}$ & $20^{\circ} \mathrm{C}$ & $25^{\circ} \mathrm{C}$ & $30^{\circ} \mathrm{C}$ & $35^{\circ} \mathrm{C}$ & $40^{\circ} \mathrm{C}$ & $45^{\circ} \mathrm{C}$ \\
\hline 1 & $\begin{array}{ll}\text { Baniče }- & \text { river } \\
\text { Pena/Tetovo } & \\
\end{array}$ & 10 & $27-30$ & - & - & - & - & - & - & - \\
\hline 2 & Dobrevo/Zletovo & 8 & 28 & 0.4 & 0.3 & 0.1 & - & - & - & - \\
\hline 3 & $\begin{array}{l}\text { Drvoš- } \\
\text { Baldovci/Strumica }\end{array}$ & 5 & 29 & - & - & - & - & - & - & - \\
\hline 4 & Gorničet/Gevgelija & 5 & 24 & - & - & - & - & - & - & - \\
\hline 5 & Istibanja/Vinica & 73 & 65 & 15.3 & 13.8 & 12.2 & 10.7 & 9.2 & 7.8 & 6.1 \\
\hline 6 & Zdravevci/Kratovo & 20 & $20-50$ & 2.8 & 2.4 & 1.9 & 1.5 & 1.1 & 0.7 & 0.3 \\
\hline 7 & Rakliš/Radoviš & $2-3$ & 27 & 0.1 & - & - & - & - & - & - \\
\hline 8 & Sabota Voda/Veles & $3,5-4$ & $90-120$ & - & - & - & - & - & - & - \\
\hline 9 & Smokvica/Gevgelija & 120 & 65 & 25.1 & 22.6 & 20.1 & 17.6 & 15.1 & 12.6 & 10.0 \\
\hline 10 & $\begin{array}{l}\text { Strnovec/Staro } \\
\text { Nagoričane }\end{array}$ & 14,4 & 39 & 4.9 & 3.9 & 2.9 & 1.9 & 1.0 & - & - \\
\hline 11 & Toplec/Dojran & - & 40 & - & - & - & - & - & - & - \\
\hline 12 & $\begin{array}{l}\text { Topli dol \& } \\
\text { Mrežičko- R'žanovo/ } \\
\text { Kavadarci }\end{array}$ & 2 & 27 & 0.1 & - & - & - & - & - & - \\
\hline 13 & Volkovo/Skopje & 20 & 25 & 0.8 & 0.4 & - & - & - & - & - \\
\hline
\end{tabular}

Source: Modified upon [3,4] and authors' content analysis

With financial support and capital investments, modern and attractive spa complexes may be developed. A way out may be detected in foreign investments or public-private partnerships. Having in mind the therapeutic benefit of balneology, the marginalized locations with geothermal potential may gain an added value. As such, besides the "basic spa tourism product" derived from the balneology treatment, a new dimension may be added. Namely, the new spa centers would be in less known locations in North Macedonia (like Vinica (Istibanja), Radoviš (Rakleš), or Zletovo (Dobrevo)), which are rural areas with ambient full of positive energy and good vibrations. This may put a focus on a "new spa tourism product" based on nature and pure environment that may result in a comprehensive satisfaction of tourists and visitors. Regardless of the perception and the image while experiencing individual leisure and recreational tourism services, the health issue is always a top priority.

Furthermore, the paper highlights the less-known geothermal locations which are dispersed over the territory of North Macedonia and draws attention to how to exploit their geothermal potential for developing new spa tourism resorts. Based upon secondary sources, the study adds to the literature on the issue of spa tourism development. It was found that North Macedonia is rich in thermal and thermo-mineral waters with potential for spa tourism development, which currently is at a low level of utilization due to the lack of investments.

Finally, the paper urges tourism policymakers to create new insights and tailor new strategic approaches to increase the number of visits and nights spent in current spas in North Macedonia, but also to promote new balneotherapy and wellness destinations.

Besides balneology as the main applicative form, some further utilization may be included thus supporting local, but also regional economic development. This may include greenhouse heating, plastic houses heating, flower cultivating, fish cultivating, cultivation of medical plants, drying of agricultural products and tobacco, district heating, preparation of sanitary warm water, etc. In cases with a high temperature of the water 
sufficient for technical feasibility, power generation may be applicable as well. So, the geothermal resources are a solid base for initiating substantial projects for supporting and enhancing the modest economic development of North Macedonia.

\section{REFERENCES}

[1] Batev, T. Thermomineral springs in Macedonia as Factor for Development of Spa Tourism (in Macedonian), Proceedings of the Pedagogical Academy “Goce Delčev" - Štip, 1979.

[2] Delipetrev, M., Delipetrev, T., Mitanovska, A., Risteska, A., Blažev, K., Delipetrev, B., \& Dimov, G. Geothermal energy, renewable and ecologic source of energy (in Macedonian), 7th international symposium Podeks-Poveks 2014, 14-15.11.2014, Radoviš, Macedonia.

[3] Geothermal energy in Macedonia, Energy efficiency (in Macedonian) https://energetskaefikasnost.info/geotermalnata-energija-vo-makedonija/, (accessed on 22.02.2021).

[4] Geothermal sources in Macedonia (in Macedonian) http://www.mn.mk/kultura/1 2867\&sa=U\&ved=2ahUKEwjDnb_nuf3uAhVI4YUKHYJ7CdYQFjABegQIBxAB\&usg=AOvVa w1SDPNGNTui_UAdmrONa08w, (accessed on 22.02.2021).

[5] Gorgieva, M., Popovski, K. Thermal spas in Macedonia. In: Proceedings of the International Workshop on Balneology and Water Tourist Centers International Geothermal Days "Germany 2001”, 21-22.09.2001, Bad Urach, Germany (pp 37-48), 2001.

[6] Hartai, É. The geothermal gradient. 2011. https://regi.tankonyvtar.hu/hu/ tartalom/tamop425/0033_SCORM_MFFTT600120-EN/sco_03_03.scorm (accessed 20.02.2021).

[7] Lund, J. W. Taking the Waters" Introduction to Balneology, Geo-Heat Center Bulletin, vol. 21, No. 3, Klamath Falls, OR (USA), 2020.

[8] Madanoglu, M. Hotel Spas - Profit Centers, published at HospitalityNET Web Site, https://www.hospitalitynet.org/file/152006347.pdf, (accessed on 22. 03.2021).

[9] Markovic, J. Spas of Jugoslavia (in Serbian), Turistička štampa, Belgrade 1980.

[10] Popovska-Vasilevska, S., \& Armenski, S. Geothermal potential of Macedonia and its utilization. In: Papic, P. (Ed.), Mineral and thermal waters of Southeastern Europe, Springer, pp 131-146, 2016.

[11] Porowski A. Mineral and Thermal Waters. In: Meyers R. (eds) Encyclopedia of Sustainability Science and Technology, Springer, New York, NY, 2018.

[12] Statistical Office of the Republic North Macedonia. Online data http://makstathttp://makstat.stat.gov.mk/PXWeb/pxweb/mk/MakStat/MakStat_TirizamUgostitel_

Turizam_TuristiNokevanja/600_Turizam_RM_ObjektiGod_ml.px/table/tableViewLayout2/?rxid= 46ee0f64-2992-4b45-a2d9-cb4e5f7ec5ef (accessed on 20. 02.2021).

[13] Suess, E., Sollas, H. B C., \& Sollas, W. J. The face of the Earth (Das Antlitz der Erde), Translated by Hertha B. C. Sollas under the direction of W. J. Sollas, Oxford, 1904.

[14] Trajkova, S. Renewable energy resources - recycling hard communal waste (in Macedonian) MSc. Thesis, Goce Delcev University - Stip, 2011.

[15] UNECE. Environmental performance reviews North Macedonia, Third Review, UN: Geneva, 2019.

[16] Vasileva, D. Balneology and hydrotherapy (in Macedonian), Goce Delčev University - Štip, North Macedonia, 2020. 